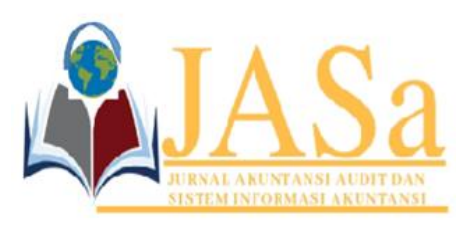

JASa (Jurnal Akuntansi, Audit dan Sistem Informasi Akuntansi)

Vol. 5 No.1/ April 2021

ISSN 2550-0732 print / ISSN 2655-8319 online

DOI; $10.36555 /$ jasa.v5i1.1512

\title{
CORPORATE SOCIAL RESPONSIBILITY DISCLOSURE ON TAX AVOIDANCE
}

\author{
Lena Herlina \\ Universitas Padjadjaran, Indonesia \\ Lena19002@mail.unpad.ac.id
}

\begin{abstract}
Corporate social responsibility (CSR) is the commitment of a company or the business world to contribute to sustainable economic development by paying attention to corporate social responsibility and emphasizing the balance between attention to economic, social, and environmental aspects. If the company becomes a tax evoidance, there will be a shortage of tax revenue which will lead to hostility and damage to the company's reputation. Ultimately corporate tax evasion will result in losses for society. Thus, tax avoidance should be regarded as socially irresponsible.This study was conducted to examine the effect of corporate social responsibility disclosure on tax avoidance. In this study, the disclosure of corporate social responsibility is measured by the GRI-G4 standard and the measurement of tax avoidance using the total book tax difference (BTD) proxy. The data analysis of this study used simple regression with $\alpha=5 \%$. The population chosen in this study were 55 manufacturing companies in various industrial sectors and the food and beverage subsector consumption which were listed on the Indonesia Stock Exchange for 4 years in 2015-2018 using the purposive sampling method. To obtain a sample of 18 companies that meet the criteria. The results of this study indicate that the disclosure of corporate social responsibility has an effect on tax avoidance.
\end{abstract}

Keywords: Disclosure of Corporate Social Responsibility, Tax Avoidance

\section{INTRODUCTION}

Taxes are the largest source of internal revenue in the APBN. State revenue from the tax sector continues to increase from year to year. The following shows the proportion of tax revenue to the state budget for the period 22015 to 2016 .

Table 1 The Role of Taxes in the 2015 SD 2016 State Budget

\begin{tabular}{|c|c|c|c|c|}
\hline & \multicolumn{2}{|c|}{2015} & \multicolumn{2}{|c|}{2016} \\
\hline & $\begin{array}{c}\text { State } \\
\text { Budget }\end{array}$ & APBNP & State Budget & APBNP \\
\hline $\begin{array}{l}\text { A. State Revenue and Grants } \\
\text { I. Domestic Revenue } \\
\text { 1. Tax Revenue } \\
\text { 2. Non-tax State Revenues }\end{array}$ & $1,796.9$ & $1,764.9$ & $1,822.5$ & $1,786.2$ \\
\hline \multirow{4}{*}{ II. Grant Receipt } & 1,793.6 & $1,761.6$ & $1,820.5$ & $1,784.2$ \\
\hline & $1,201.7$ & $1,489.3$ & $1,546.7$ & $1,539.2$ \\
\hline & 588.6 & 269.1 & 273.8 & 245.1 \\
\hline & 3,3 & 3,3 & 2.0 & 2.0 \\
\hline
\end{tabular}




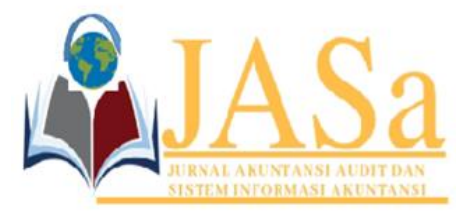

JASa (Jurnal Akuntansi, Audit dan Sistem Informasi Akuntansi)

Vol. 5 No.1/ April 2021

ISSN 2550-0732 print / ISSN 2655-8319 online

DOI; $10.36555 /$ jasa.v5i1.1512

Tax is a source of state income that comes from the people. For the state, tax collection is an important source of revenue which is then returned to the community, through routine spending and development expenditures. Conversely, for taxpayers, it is an expense that will reduce income or net income. This is what causes companies to avoid tax. According to the Indonesian Minister of Finance Sri Mulyani in Republika Online 2016 , said that the government's tax revenue in recent years was far below the target, and taxpayer compliance to reporting their assets was still low, thus making the tax ratio small.

Tax avoidance is a way to legally avoid taxes that do not violate tax regulations because it is considered a practice that takes advantage of loopholes in the tax law that will affect state revenue from the tax sector (Hadi \& Mangoting, 2014). Tax avoidance is a reduction in the amount of explicit taxes, where tax avoidance is a series of tax planning activities (Hanlon \& Heitzman, 2010).

The phenomenon of tax avoidance or tax avoidance in Indonesia and various parts of the world is increasing from time to time. Suzuki Motor Corp in 2016 also evaded taxes by using their motorcycle racing business to hide funds of 300 million yen (Rp. 38.6 billion) to trick local governments into not being subject to higher taxes. (Suzuki Caught Embracing Taxes? - AutonetMagz, nd).

Corporate social responsibility (CSR) is the commitment of a company or the business world to contribute to sustainable economic development by paying attention to corporate social responsibility and emphasizing the balance between attention to economic, social, and environmental aspects (Wolmarans \& Sartorius, 2009). If the company becomes a tax evoidance, there will be a shortage of tax revenue which will lead to hostility and damage to the company's reputation. Ultimately corporate tax evasion will result in losses for society. Thus, tax avoidance should be regarded as socially irresponsible.

From the description above, it can be concluded that tax and CSR are both aimed at the general welfare. The difference is that taxes are managed by the central and regional governments which are then distributed to the general public while CSR is managed by companies which are then distributed to the general public. However, many companies do not understand the importance of CSR practices. Their orientation is still limited to whether CSR practices are profitable and have not integrated the value of CSR in their respective operational strategies and decision making (Wolmarans \& Sartorius, 2009).

Research that examines the effect of Corporate Social Responsibility (CSR) and the GCG mechanism on tax avoidance has been done before. Research conducted by Lanis \& Richardson (2012) used a sample of listed companies in Australia totaling 408 companies with the 2008 and 2009 research years the regression results showing a negative relationship. Research Hoi (2013) about the relationship between CSR and tax avoidance shows that companies with excessive irresponsible CSR activities are more aggressive in avoiding taxes, in contrast to research Susanti (2018) which shows that CSR does not affect tax avoidance. 


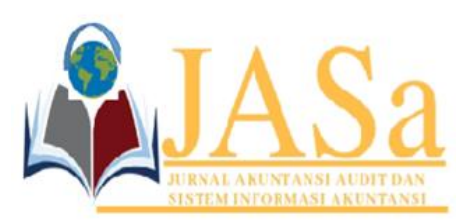

JASa (Jurnal Akuntansi, Audit dan Sistem Informasi Akuntansi)

Vol. 5 No.1/ April 2021

ISSN 2550-0732 print / ISSN 2655-8319 online

DOI;10.36555/jasa.v5i1.1512

Based on the background descriptions that have been discussed previously, the authors identified the main issues discussed in this study, namely How does disclosure of Corporate Social Responsibility influence tax avoidance? Hypothesis: CSR disclosure affects tax avoidance

\section{METHODS}

This research uses descriptive verification research. Data collection sources use secondary data. This data is in the form of financial statements of various industrial sector manufacturing companies and the food and beverage sub-sector consumption sector which are listed on the Indonesia Stock Exchange. The data source comes from the Indonesia Stock Exchange through the IDX website, namely(PT Bursa Efek Indonesia, nd).

\section{Population and Sample}

The population used in this study are manufacturing companies in various industrial sectors that have gone public and listed on the Indonesia Stock Exchange. This is based on several reasons concerning data availability, differences in characteristics, and sensitivity to events. A company listed on the Indonesia Stock Exchange means that its financial statements have been published so that the availability and ease of obtaining data can be fulfilled

The sample selection in this study using the purposive sampling method. Some of the criteria that must be met in determining the sample in this study are: The company includes manufacturing companies in various industrial sectors and the food \& beverage sub-sector listed on the IDX and publishing consistent and complete audited financial reports as of December 31st from 2015-2018 and not delisted during the research observation period. Company profits are positive during the study period. Financial reports using the rupiah currency

\section{Corporate Social Responinility (CSR)}

CSR is the entrepreneur's obligation to formulate policies, make decisions, or follow the desired line of action in terms of the goals and values of society (Rusmanto \& Williams, 2015). The measurement used in assessing CSR disclosure is the GRI-G4 standard. In the GRI-G4 standard, performance indicators are divided into three main components, namely: Economy (9 items), Environment (34 items), Social (48 items) Furthermore, the total value of disclosure is used to measure the CSR index (Sembiring 2005). The formulas that can be used are as follows:

Information :

$$
C S R l j=\frac{\sum x y i}{\mathrm{Ni}}
$$

CSRlj = Broad index of disclosure of corporate social and environmental responsibility

$\sum \mathrm{Xyi}=$ value $1=$ if item $\mathrm{Yi}$ is disclosed; $0=$ if item $\mathrm{Yi}$ is not disclosed

$\mathrm{Ni} \quad=$ number of items for the company I, ni $\leq 90$ 


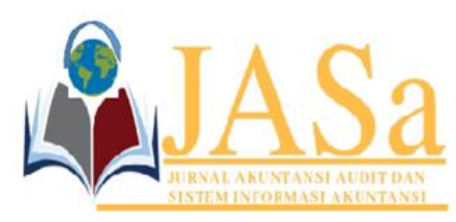

\author{
JASa (Jurnal Akuntansi, Audit dan Sistem Informasi Akuntansi) \\ Vol. 5 No.1/ April 2021 \\ ISSN 2550-0732 print / ISSN 2655-8319 online \\ DOI;10.36555/jasa.v5i1.1512
}

\title{
Tax Avoidance
}

According to Suandy (2011), Tax Avoidance is an engineering "tax affairs" which is still within the framework of taxation provisions (lawful). Tax avoidance is measured using a book-tax gap proxy. The book-tax gap or commonly known as book-tax differences are differences in accounting profit and taxable profit that occur because of differences between taxation regulations and accounting regulations. Book tax differences formula(Huseynov \& Klamm, 2012):

Total BTD $=\frac{\text { EBIT-Taxable profit }}{\text { Total assets of the previous year }}$

\section{Data Analysis}

The data analysis used in this research is simple regression analysis.

\section{RESULTS AND DISCUSSION}

To see the effect of disclosure of Corporate Social Responsibility (CSR) on tax avoidance, researchers used simple regression analysis using SPSS 24.0. The results of the regression analysis are as follows:

Table 2 Regression Analysis Results

\begin{tabular}{|c|c|c|c|c|c|c|}
\hline & \multirow[b]{2}{*}{ Model } & \multicolumn{2}{|c|}{$\begin{array}{c}\text { Unstandardized } \\
\text { Coefficients }\end{array}$} & \multirow{2}{*}{$\begin{array}{c}\text { Standardized } \\
\text { Coefficients } \\
\text { Beta }\end{array}$} & \multirow{3}{*}{$\frac{\mathrm{T}}{4.085}$} & \multirow{3}{*}{$\begin{array}{l}\text { Sig. } \\
0.000\end{array}$} \\
\hline & & B & Std. Error & & & \\
\hline 1 & (Constant) & 0.039 & 0.010 & & & \\
\hline & CSR & -0.065 & 0.017 & $-0,528$ & $-3,867$ & 0,000 \\
\hline
\end{tabular}

Source: SPSS Output Results

Based on the data from table 4:12, it can be seen that the regression equation of disclosure of Corporate Social Responsibility (CSR) on tax avoidance is as follows:

$$
\mathrm{Y}=0.039-0.065 \mathrm{X}
$$

From the results of the simple linear regression equation, each variable can be interpreted as follows: The constant value is 0.039 , meaning that if the CSR variable $(\mathrm{X})$ is 0 , then the tax avoidance variable $(\mathrm{Y})$ will have a constant value of 0.039 units. Each increase in CSR will cause a decrease in tax avoidance by -0.065 units. A partial test is conducted to test the partial effect of each independent variable used in the model on the dependent variable. The results of the t statistical test can be seen in the following table:

Table 3 T-Test Results

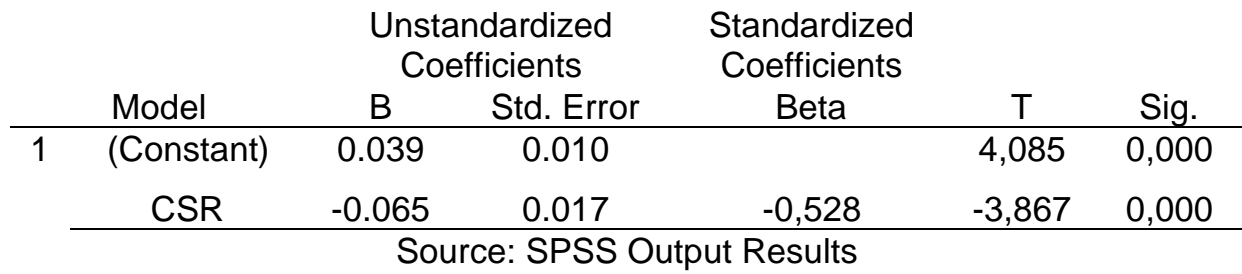




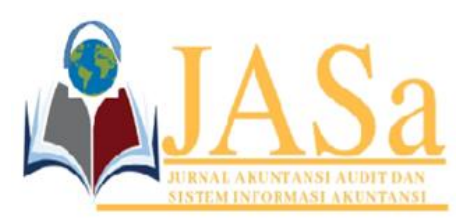

\author{
JASa (Jurnal Akuntansi, Audit dan Sistem Informasi Akuntansi) \\ Vol. 5 No.1/ April 2021 \\ ISSN 2550-0732 print / ISSN 2655-8319 online \\ DOI; $10.36555 /$ jasa.v5i1.1512
}

Based on the results of data processing where the probability value of $0.000(\mathrm{p}$ $<0.05$ ), it can be concluded that $\mathrm{Ha}$ is accepted, meaning that the disclosure of Corporate Social Responsibility (CSR) affects tax avoidance at a significant level of $5 \%$._Analysis of the coefficient of determination is an analysis used to determine the magnitude of the influence of an independent variable on the dependent variable. $R$ Square is the index of determination in the model in which the independent variable is included.

\begin{tabular}{|c|c|c|c|c|}
\hline Model & & $\begin{array}{c}\mathrm{R} \\
\text { Square }\end{array}$ & Adjusted R & Std. An error of the \\
\hline 1 & $.542 a$ & 0.294 & 0.267 & 0.0157342 \\
\hline
\end{tabular}

Table 4 shows that the coefficient of determination is $0.294=29.4 \%$. That is, the magnitude of the influence of the variable on $\mathrm{Y}$ is $29.4 \%$.

\title{
The Effect of CSR Disclosure on Tax Avoidance.
}

Based on the results of hypothesis testing and t-test, the hypothesis is accepted that CSR disclosure affects tax avoidance. Because the significance value of 0.000 is smaller than $(\mathrm{a})=0.05$. These results indicate a negative effect, which means that the greater the value of CSR disclosure carried out by the company, the lower the level of tax avoidance activity. According to Hoi et al (2013), companies with lower CSR are considered socially irresponsible, so they are more aggressive in tax avoidance.

The concept of legitimacy shows the company's responsibility to the community. To be able to maintain its survival, the company seeks some kind of legitimacy or recognition from investors, creditors, consumers, the government, and the surrounding community. (Hidayati \& Fidiana, 2017). The higher the level of CSR disclosure of a company, the higher the company's reputation in the public eye. According to Winarsih and Kusufi (2014), a good reputation will also be obtained from the payment of taxes.

\section{CONCLUSION}

Based on the results of research and discussion, the study concludes that disclosure of corporate social responsibility affects tax avoidance in manufacturing companies in various industrial sectors and the food \& beverage sub-sector consumer goods sector on the Indonesia Stock Exchange.

\section{REFERENCES}

Geliat Ekonomi 2016, Tax Amnesty, dan Kinerja Sri Mulyani / Republika Online. (n.d.). Retrieved March 22, 2021, from https://www.republika.co.id/berita/jurnalismewarga/wacana/17/01/02/oj4wzq336-geliat-ekonomi-2016-tax-amnesty-dan-kinerjasri-mulyani 


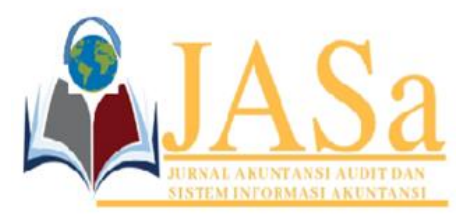

JASa (Jurnal Akuntansi, Audit dan Sistem Informasi Akuntansi)

Vol. 5 No.1/ April 2021

ISSN 2550-0732 print / ISSN 2655-8319 online

DOI;10.36555/jasa.v5i1.1512

Hadi, J., \& Mangoting, Y. (2014). Pengaruh Struktur Kepemilikan dan Karakteristik Dewan Terhadap Agresivitas Pajak. Tax \& Accounting Review.

Hanlon, M., \& Heitzman, S. (2010). A review of tax research. In Journal of Accounting and Economics. https://doi.org/10.1016/j.jacceco.2010.09.002

Hidayati, N., \& Fidiana. (2017). PENGARUH CORPORATE SOCIAL RESPONSIBILITY DAN GOOD CORPORATE GOVERNANCE TERHADAP PENGHINDARAN PAJAK Nurul Hidayati Fidiana Sekolah Tinggi Ilmu Ekonomi Indonesia ( STIESIA ) Surabaya. Jurnal IImu Dan Riset Akuntansi.

Hoi, C. K., Wu, Q., \& Zhang, H. (2013). Is corporate social responsibility (CSR) associated with tax avoidance? Evidence from irresponsible CSR activities. Accounting Review. https://doi.org/10.2308/accr-50544

Huseynov, F., \& Klamm, B. K. (2012). Tax avoidance, tax management and corporate social responsibility. Journal of Corporate Finance. https://doi.org/10.1016/j.jcorpfin.2012.06.005

Lanis, R., \& Richardson, G. (2012). Corporate social responsibility and tax aggressiveness: An empirical analysis. Journal of Accounting and Public Policy. https://doi.org/10.1016/j.jaccpubpol.2011.10.006

PT Bursa Efek Indonesia. (n.d.).

Rusmanto, T., \& Williams, C. (2015). Compliance Evaluation on CSR Activities Disclosure in Indonesian Publicly Listed Companies. Procedia - Social and Behavioral Sciences. https://doi.org/10.1016/j.sbspro.2015.01.348

Suandy, E. (2011). Perencanaan Pajak. In Perencanaan Pajak (Edisi 5).

Susanti, E. (2018). Pengaruh Profitabilitas, Leverage, Sales Growth dan Ukuran Perusahaan terhadap Penghindaran Pajak (Studi Empiris pada Perusahaan Sektor Pertambangan dan Sektor Pertanian yang Listing di Bursa Efek Indonesia 2012-2017). Skripsi. Universitas Islam Indonesia Yogyakarta.

Suzuki Ketahuan Gelapkan Pajak? - AutonetMagz. (n.d.). Retrieved December 12, 2020, from https://autonetmagz.com/suzuki-ketahuan-gelapkan-pajak/45209/

Winarsih, Rina; Prasetyono; Kusufi, M. S. (2014). Pengaruh Good Corporate Governance dan Corporate Sosial Responsibility Tindakan Pajak Agresif. SNA 17 Mataram, Lombok Universitas Mataram 24-27 Sept 2014.

Wolmarans, H., \& Sartorius, K. (2009). Corporate social responsibility: The financial impact of black economic empowerment transactions in South Africa. In South African Journal of Economic and Management Sciences. https://doi.org/10.4102/sajems.v12i2.275. 